\title{
Kajian Strategi Pengelolaan Sampah
}

\author{
Dermawan $^{1}$, Lahming², Moh. Ahsan S. Mandra² \\ Universitas Al Asyariah Mandar, Sulawesi Barat \\ PKLH PPS Universitas Negeri Makassar, Sulawesi Selatan, Indonesia ${ }^{2}$ \\ dermawanaziz77@gmail.com
}

(C) 2018 - UEJ Program Studi Pendidikan Kependudukan dan Lingkungan Hidup

Universitas Negeri Makassar. Ini adalah artikel dengan akses terbuka dibawah Licensi CC BY-NC-4.0 (http:/creativecommons.org/licenses/by-nc/4.0)

\begin{abstract}
.
Pengelolaan sampah harus dilakukan secara komprehensif dan terpadu dari hulu ke hilir agar memberikan manfaat secara ekonomi, sehat bagi masyarakat, dan aman bagi lingkungan, serta dapat mengubah perilaku masyarakat. Selain itu, pengelolaan sampah juga membutuhkan adanya kepastian hukum, kejelasan tanggung jawab dan pembagian kewenangan selain untuk peran masyarakat dan dunia usaha dalam pengelolaan sampah dapat mendukung secara system pengelolaan sampah. Kebijakan Strategi Nasional Pengembangan Pengelolaan Persampahan diuraikan bahwa penanganan dan pengurangan sampah berbasis rumah tangga dengan menerapkan 3R: Reduce. Reuse, dan Recycle. maka dapat disimpulkan bahwa penanganan dan pengelolaan sampah tidak cukup didukung oleh teknologi, sarana dan prasarana serta dana yang memadai, tetapi yang lebih penting adalah partisipasi seluruh komponen masyarakat secara langsung atau tidak langsung, baik secara kelompok maupun individu. Persoalan sampah bisa berkurang jika pemerintah bersinergi dengan masyarakat serta memberikan porsi yang semakin meningkat untuk berperan serta aktif dalam pengelolaan sampah.
\end{abstract}

Keywords: strategi, pengelolaan, sampah, masyarakat

\section{PENDAHULUAN}

Berdasarkan data Kementerian Lingkungan Hidup (KLH) (2017) setiap orang membuang sampah kurang lebih 0,7 kg per hari/orang, $175 \mathrm{ribu}$ ton/hari, 64 juta ton/tahun. Sedangkan pemerintah baru mampu mengumpulkan dan mengangkut sampah kurang lebih 60-70\% dari total jumlah sampah yang ada Untuk mengatasi masalah tersebut, maka sampah haruslah dikelola dengan baik disertai upaya pemanfaatannya sehingga diharapkan untuk dapat memberikan keuntungan berupa nilai tambah terhadap lingkungan.

Pengelolaan sampah harus dilakukan secara komprehensif dan terpadu dari hulu ke hilir agar memberikan manfaat secara ekonomi, sehat bagi masyarakat, dan aman bagi lingkungan, serta dapat mengubah perilaku masyarakat. Dengan model pengelolaan sampah yang tepat maka lingkungan sekitar dapat terjaga serta masyarakat terhindar dari berbagai penyakit. Selain itu, pengelolaan sampah juga membutuhkan adanya kepastian hukum, kejelasan tanggung jawab dan pembagian kewenangan selain untuk peran masyarakat dan dunia usaha dalam pengelolaan sampah dapat mendukung secara system pengelolaan sampah, hal ini sekaitan dengan Undang-Undang RI no 18 tahun 2008 tentang Pengelolaan Sampah di Indonesia. Undang-undang ini mengatur tentang pengelolaan sampah, pembagian kewenangan dan penyelenggaraannya. (Firman L. Sahwan dkk, 2010).

Sampah merupakan akibat dari aktifitas manusia yang juga merupakan konsekuensi kemajuan dan perkembangan suatu wilayah terutama perkotaan. Artinya, kemajuan dan perkembangan serta pertambahan penduduk yang diiringi oleh perubahan pola konsumsi masyarakat menimbulkan bertambahnya volume, jenis dan karakteristrik sampah yang semakin beragam (UUD No. 18 Tahun 2008). Berdasarkan UU No 18 pasal 19 tahun 2008 tentang pengelolaan sampah, dan Peraturan Menteri (PERMEN) Pekerjaan Umum No. 21/ PRT/ M 2006, tentang Kebijakan Strategi Nasional Pengembangan Pengelolaan Persampahan diuraikan bahwa penanganan dan pengurangan sampah berbasis rumah tangga dengan menerapkan 3R: Reduce. Reuse, dan Recycle. Artikel ini akan menguraikan tentang strategi pengelolaan sampah bersarkan kajian teori yang ada. 


\section{PENGELOLAAN SAMPAH}

Pengelolaan sampah tidak hanya menyangkut aspek teknis semata, namun yang jauh lebih penting adalah menyangkut masalah pengetahuan dalam rangka mendorong perubahan sikap dan pola pikir menuju terwujudnya masyarakat yang rama lingkungan dan berkelanjutan (Suryani, 2017).

Undang-Undang (UU) Nomor 32 tahun 2009 pasal 1 ayat (2) mendefinisikan perlindungan dan pengelolaan lingkungan hidup sebagai upaya sistematis dan terpadu yang dilakukan untuk melestarikan fungsi lingkungan hidup dan mencegah terjadinya pencemaran dan / atau kerusakan lingkungan hidup yang meliputi perencanaan, pemanfaatan, pengendalian, pemeliharaan, pengawasan dan penegakan hukum. Tujuan umum lingkungan hidup adalah terwujudnya pembangunan berkelanjutan dan berwawasan lingkungan.

Konsep dasar pengelolaan sampah merupakan suatu upaya untuk mencegah terjadinya penumpukan sampah, dan menekankan dampak negatif yang mungkin terjadi, serta bagaimana pemanfaatannya (Sahil, 2016). Bertolak dari konsep dasar tersebut, para ahli melakukan pengkajian, baik secara teoritis maupun secara empirik. Kajian akademik mengenai pengelolaan sampah dilakukan oleh para ahli lingkungan dan kelompok pencinta lingkungan.

Dari sedikit gambaran mengenai sampah tersebut, kita dapat menelaah dan membuat suatu rangkaian proses bagaimana sampah yang dihasilkan dapat dikelola menjadi sampah yang lebih ramah lingkungan dan bahkan dimanfaatkan lagi untuk kegunaan yang lain. Berikut adalah poin-poin penting dalam pengelolaan sampah dan rangkaian pembuangan sampah yang ideal, yang harus dilakukan dalam rangka pengelolaan sampah yang ideal yaitu:

1. Pemilahan meliputi pemilahan dari sumber dihasilkannya sampah yang terdiri dari sampah organik dan anorganik, pemilihan sampah yang masih memilki sumber energi tinggi dan pemanfaatan kembali sampah yang memiliki resources bernilai tinggi.

2. Pewadahan meliputi pewadahan individual disediakan di tingkat rumah dengan menyediakan 2 unit penampungan sampah terdiri dari sampah organic dan anorganik, pewadahan komunal (Kontainer atau TPS) khusus imtuk menampung berbagai jenis sampah baik organik maupun anorganik seperti untuk sampah plastik, gelas, pakaian/tekstil, logam, sampah besar, sampah B3 (batu, baterai, balon lampu neon dll).

3. Pengumpulan meliputi waktu pengiunpulan door to door setiap 1 sampai 2 hari dan waktu pengumpulan sampah dari TPS $1 \mathrm{x}$ seminggu.

4. Pengangkutan sampah dengan compactor truk berbeda untuk setiap jenis sampah.

5. Daur ulang yaitu pemanfaatan kembali kertas bekas yang dapat digunakan terutama untuk keperluan eksternal, plastik bekas diolah kembali imtuk dijadikan sebagai biji plastik untuk dijadikan berbagai peralatan rumah tangga seperti ember dll, peralatan elektronik bekas dipisahkan setiap komponen penggunaannya (logam, plastik / kabel, baterai dll) dan dilakukan pemilihan untuk setiap komponen yang dapat digunakan kembali, gelas/botol kaca dipisahkan berdasarkan warna gelas (putih, hijau, dan gelap) dihancurkan, dan limbah lingkungan lain berupa daun-daunan.

6. Kompos meliputi sarana percontohan, penyuluhan, pelatihan dan pembinaan pengomposan skala lingkungan yang dikelola oleh masyarakat. untuk menumbuhkan kesadaran bahwa sampah rumah tangga harus dikelola di sumbernya. 


\section{PEMBAGIAN SAMPAH}

Menurut asalannya sampah dibagi dalam :

1. Sampah buangan rumah tangga; termasuk sampah biasa, bahan makanan, sampah sisa makanan, pembungkus makanan dan pembungkus perabotan rumah tangga, sampah sisa tumbuhan kebim dan sebagainya.

2. Sampah buangan pasar dan tempat-tempat umum (warning, toko dan sebagainya) termasuk sisa makanan, sampah pembungkus makanan dan pembungkus lainnya, sampah taman dan sebagainya

3. Sampah jalanan; termasuk diantaranya sampah debu jalanan, sampah sisa tumbuhan taman, sampah pembungkus bahan makanan dan bahan lainnya, sampah sisa makanan, sampah berupa kotoran serta bangkai hewan.

4. Sampah industri termasuk diantaranya air limbah industri, debu industri, sisa bahan baku dan bahan jadi dan sebagainya.

5. Sampah menurut jenisnya dibagi dalam:

6. Sampah organik adalah sampah termasuk diantaranya sisa bahan makanan serta sisa makanan, sisa pembungkus dan sebagainya. Keseluruhan di kenal sebagai sampah pasar serta sampah industri bahan makanan.

7. Sampah anorganik adalah sampah termasuk di antaranya berbagai jenis sisa gelas, logam, plastik dan sebagainya. Biasanya jenis ini terbagi atas sampah yang dapat dihancurkan dan yang tak dapat dihancurkan oleh mikroorganisme termasuk sampah anorganik, misalnya sisa-sisa mobil bekas, gelas, dan sebagainya.

Dasar kebijakan tentang pengelolaan sampah yaitu UU No. 18 Tahun 2008 tentang pengelolaan sampah yang menguraikan bahwa standar pengelolaan sampah di Indonesia yaitu : (1) Mengedepankan pengurangan sampah; (2) Penutupan semua TPA open dumping pada tahun 2013; (3) Monitoring kualitas lingkungan pasca penutupan TPA sampai 20 tahun

Selanjutnya Permen PU 21/PRT/2006 tentang kebijakan dan strategi nasional pengembangan sistem pengelolaan sampah menguraikan bahwa pemerintah mengembangkan kualitas lingkungan dengan pengelolaan sampah yang berbasis masyarakat. PP 81 Tahun 2012 tentang pengelolaan sampah rumah tangga dan sampah sejenis rumah tangga menguraikan bahwa :

1. Setiap orang wajib melakukan pengurangan dan penanganan sampah.

2. Pemerintah Kabupaten/Kota menyediakan fasilitas pengelolaan sampah antara lain berupa TPS 3R.

Permen PU 3 Tahun 2013 tentang penyelenggaraan sarana dan prasarana persampahan dalam penanganan sampah rumah tangga dan sampah sejenis sampah rumah tangga menguraikan bahwa :

1. Pemilahan sampah

2. Pemilahan sampah dilakukan oleh :

a. Setiap orang pada sumbernya.

b. Pengelola kawasan permukiman, kawasan komersial, kawasan industri, kawasan khusus, fasilitas umum, fasilitas sosial, dan fasilitas lainnya.

c. Pemerintah Kabupaten/Kota.

\section{STRATEGI PENGELOLAAN SAMPAH}

Menurut Munarika (2018) strategi didefinisikan sebagai suatu proses penentuan rencana para pemimpin puncak yang berfokus pada tujuan jangka panjang organisasi, disertai penyusunan suatu cara atau upaya bagaimana agar tujuan tersebut dapat dicapai. Sedangkan Glueck dan Jauch (Qomariah, 2014) strategi adalah rencana yang disatukan, 
luas dan berintegrasi yang menghubungkan keunggulan strategi dengan tantangan lingkungan, dirancang untuk memastikan tujuan utama dapat dicapai melalui pelaksanaan yang tepat oleh organisasi.

Anam (2013) menyatakan bahwa strategi adalah penetapan sasaran jangka panjang organisasi, serta penerapan serangkaian tindakan dan alokasi daya yang penting untuk mencapai tujuan tersebut. Fitotin (2014) mengemukakan bahwa strategi merupakan tindakan yang bersifat incremental (terus meningkat) dan terus menerus, serta dilakukan berdasarkan sudut pandang tentang apa yang diharapkan pelanggan dimasa depan. Berdasarkan uraian diatas maka strategi adalah suatu rencana yang disusun dengan serangkaian tindakan untuk mencapai tujuan tertentu.

Berbagai strategi pengelolaan sampah sebagai berikut.

Dalam Trina et al (2016), strategi yang digunakaan dalam pengelolaan limbah elektronik melalui pengembangan infrastruktur ramah lingkungan diketahui bahwa strategi prioritas yang harus dilakukan saat ini adalah mengembangkan infrastruktur pengelolaan limbah elektronik ramah lingkungan sehingga sistem pengolahan dan daur ulang dapat berjalan dengan skema ramah lingkungan.

Kurniati et al (2016), strategi pengelolaan sampah dilakukan dengan memisahkan sampah anorganik dan sampah organik. Pada sampah anorganik akan di daur ulang sedangkan sampah organik dibuat pupuk dan bioenergi.

Atriningsih (2008), strategi pengelolaan sampah rumah tangga berbasis masyarakat dilakukan dengan konsep 3R yaitu Reuse, Reduce, dan Recycle. Reuse berarti menggunakan kembali sampah yang masih dapat digunakan untuk fungsi yang sama ataupun fungsi lainnya. Reduce berarti mengurangi segala sesuatu yang mengakibatkan sampah.. Recycle berarti mengolah kembali (daur ulang) sampah menjadi barang atau produk baru yang bermanfaat.

Sumarto (2016) menyatakan strategi mempercepat proses pengomposan dapat dipercepat dengan beberapa strategi. Secara umum strategi untuk mempercepat proses pengomposan dapat dikelompokan menjadi tiga, yaitu: memanipulasi kondisi/faktor-faktor yang berpengaruh pada proses pengomposan, menambahkan organisme yang dapat mempercepat proses pengomposan seperti mikroba pendegradasi bahan organik dan vermikompos (cacing) dan menggabungkan strategi pertama dan kedua.

\section{KESIMPULAN}

Berdasarkan hasil pembahasan diatas, maka dapat disimpulkan bahwa penanganan dan pengelolaan sampah tidak cukup didukung oleh teknologi, sarana dan prasarana serta dana yang memadai, tetapi yang lebih penting adalah partisipasi seluruh komponen masyarakat secara langsung atau tidak langsung, baik secara kelompok maupun individu. Persoalan sampah bisa berkurang jika pemerintah bersinergi dengan masyarakat serta memberikan porsi yang semakin meningkat untuk berperan serta aktif dalam pengelolaan sampah.

\section{REFERENSI}

Anam, K., 2013. Strategi Pemasaran dan Implementasinya dalam Lembaga Pendidikan. Ta'allum: Jurnal Pendidikan Islam, 1(2), pp.159-170.

Artiningsih, N.K.A., 2008. Peran serta masyarakat dalam pengelolaan sampah rumah tangga (Studi kasus di Sampangan dan Jomblang, Kota Semarang) (Doctoral dissertation, program Pascasarjana Universitas Diponegoro).

Firman, L.S. 2010. Pengelolaan Sampah Pemukiman berbasis Masyarakat:studi Kasus Jakarta Selatan 
FItrotin Jamilah. 2014. Strategi Penyelesaian Sengketa Bisnis. Medpress Digital, Yogyakarta

Kurniaty, Y., Nararaya, W.H.B., Turawan, R.N. and Nurmuhamad, F., 2016. Mengefektifkan Pemisahan Jenis Sampah Sebagai Upaya Pengelolaan Sampah Terpadu Di Kota Magelang. Varia Justicia, 12(1), pp.135-150.

Munarika, n., 2018. Strategi dalam meningkatkan kepuasan anggota penabung dengan akad wadi'ah di kantor pusat baitul maal wat tamwil (BMT) pahlawan tulungagung. (Skripsi, IAIN Tulungangung).

Sahil, J., Al Muhdar, M.H.I., Rohman, F. and Syamsuri, I., 2016. Sistem pengelolaan dan upaya penanggulangan sampah di Kelurahan Dufa-Dufa Kota Ternate. BIOEDUKASI, $4(2)$.

Sumarto, S., 2016. Community engagement waste management dengan activated carbon (nano porus materials), bioarang dan kompos: mengatasi pengelolaan sampah dengan bioarang, activated carbon dan kompos bagi masya $\neg$ rakat desa parit dan kebun ix kec. Sungai gelam kab. Muara Jambi.

SURYANI, H., 2017. Model Pelatihan Motivation, Innovative, Development, Achievement (MIDA) dalam Pengelolaan Limbah Industri Pakaian Jadi (Doctoral dissertation, Pascasarjana).

Trina Ayuni, Dodik Ridho Nurrochmat, dan Nastiti Siswi Indrasti, 2016. Strategi Pengelolaan Limbah Elektronik Melalui Pengembangan Infrastruktur Ramah Lingkungan.

Risalah Kebijakan Pertanian dan Lingkungan, 3(1), Pp.78-86.

Undang-Undang Republik Indonesia Nomor18 tentang Pengelolaan Sampah

Undang-Undang Republik Indonesia Nomor 32 Tahun 2009 Tentang Perlindungan dan Pengelolaan Lingkungan Hidup.

Qomariyah, S.L., 2014. Strategies Used By The High And Low Writing Ability Students To Develop Writing Skill At Muhammadiyah University Of Surakarta (Doctoral dissertation, Universitas Muhammadiyah Surakarta). 